$\begin{array}{llllll}\text { THE T Y N D A LE } & \text { H O US E } & \text { B ULLETIN }\end{array}$

Issued twice yearly by the Tyndale Fellowship for Biblical Research, Tyndale house, Selwyn Gardens, Cambridge.

Price to non-members : 1s. $3 d$. per copy, post free.

Nos. 4 - 5 .

1958

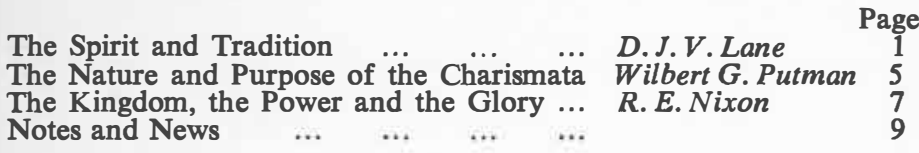

\title{
THE SPIRIT AND TRADITION
}

The first references to tradition in the Scriptures occur in the Gospels. They refer to what is called 'the traditions of the elders', and the references are anything but favourable towards them. Matthew and Mark have parallel accounts of our Lord's dealing with the old traditions of the Rabbis connected with the washing of hands before meals, the relevant passages being Matthew xv. 1-14 and Mark vii. 3ff. We do not have to consider the passages in detail for the purposes of this paper, but it is sufficient to observe that whereas the disciples were transgressing the tradition of the elders, the Pharisees and scribes in their practices were transgressing the commandment of God. God had said, 'Honour thy father and mother,' but the Jews said that ' . . . he shall not honour his father and mother'.

The important words for our purposes are 'the commandment of God' and 'God said'. The condemnation which our Lord expressed towards the Pharisees was because they were adding the opinions of sinful men to the divinely-ordained Word, through which God Himself spoke to them. Through their tradition they were removing the authority (kurosate removing the kuros) and setting aside (athetein) the Word of God.

When we look further back into this distinction between the words of the Pharisees and the Word of God, we find that what made the Old Testament the Word of God was the fact that the Holy Spirit was instrumental in causing it to be written. The New Testament is very strong on this. The Epistle to the Hebrews often ascribes the authorship of some passage of the Old Testament to the Holy Spirit Himself, and by using the present tense of the verb implies that $\mathrm{He}$ continually speaks to every generation through that passage ; e.g. iii. 7 : 'The Holy Ghost saith, To day if ye will hear his voice ..., x. 15: "The Holy Ghost also is a witness to us ...., referring to the New Covenant of Jeremiah xxxi. Mark combines the human author and the Holy Spirit in xii. 36 (RV) : 'David . . said in the Holy Spirit ... The same combination occurs in Paul's speaking to the Jews in Rome in Acts xxviii. 26 (RV): "Well spake the Holy Ghost by Isaiah the prophet ...' and in Peter's speech to the disciples about a successor to Judas, … the scripture ... which the Holy Ghost spake before by the mouth of David.' 2 Peter i. 21 confirms this view of the Holy Spirit in relation to the Scriptures; "holy men of God spake as they were moved by the Holy Ghost.'

This was the reason why the traditions of the elders could not stand alongside the Old Testament Scriptures or claim an authority with them. The traditions were the words of unaided sinful men, whereas the Scriptures were the result of the activity of God, and as a result of the ministry of the Holy Spirit what the authors wrote would be described quite legitimately as what God said. So in the parallel accounts of Matthew and Mark, Matthew says 'God' said and Mark says of the same quotation 'Moses said' (Mt. xv. 4 ; Mk. vii. 10).

So far we have no problem, but then we turn into the later pages of the New Testament and find that the 'tradition' is to be held fast, kept, received, and obeyed. As Cullmann has pointed out, we find Paul using exactly the terms he had used as a Rabbi when dealing with the tradition of the elders. 
2 Thes. ii. 15

1 Cor. xi. 2

1 Cor. xi. 23

1 Cor. xv. 2

1 Thes. ii. 13

2 Thes. iii. 6

Rom. vi. 17

Gal. i. 9

Col. ii. 6

krateite tēn paradosin kai stēkete

kathōs paredōka humin tēn paradosin katechete

parelabon ..... paredōka

ho kai parelabete.... katechete

parelabontes

kata tēn paradosin hèn parelabosan par' hēmōn

Obedience to tupon didachēs eis hon paredothēte par' ho parelabete

Hōs parelabete

i. 12 egō parelabon

Cullmann further maintains that Paul continues to use this Jewish formula deliberately, and that paralambanein $=$ Oibbel and paradidonai $=$ Masar le.

Yet at the same time we find in Galatians i. 14 that the apostle speaks of his past zeal for the traditions of the fathers as indeed past, since God had been pleased to reveal His Son in him. The only conclusion that we can draw is that there must be some new factor introduced which was connected with the apostles and not with the Rabbis, and which radically altered the position.

We find the same problem with our Lord and His teaching. What surprised the people was that $\mathrm{He}$ taught them as one having authority and not as the scribes, with all their references to one another and to the past. Indeed, having roundly condemned the Pharisees for adding to the Scripture the traditions of men, the Lord goes on in the Sermon on the Mount to place His own teaching beside the Scripture as an authoritative commentary. 'Ye have heard that it was said to them of old time . . . but I say unto you ....'He even prefaced a series of such statements with the general principle that He had not come to destroy the Law, but to fulfil it. No part of the Law was to fail.

What, then, was the distinctive possession of the Lord which gave Him the right justly to take the teaching authority to Himself ? Is there any parallel between His position and the claims of the apostles ?

The answer to the first question is that Jesus Christ was prominently the Man of the Spirit, and in His position as the Spirit-anointed Messiah $\mathrm{He}$ had every right to interpret the Scriptures. In the beginning $\mathrm{He}$ was conceived by the Holy Ghost, and in His baptism at the beginning of His ministry the Holy Spirit descended upon Him in bodily shape as a dove. John the Baptist characterized Him as the One who was to baptize with the Holy Spirit. From the baptism, our Lord went in the fulness of the Spirit into the wilderness to be tempted, and returned in the power of the Spirit to minister. In the synagogue at Nazareth $\mathrm{He}$ deliberately applied the Servant passage of Isaiah to Himself as the One anointed upon whom the Spirit rested. In the Fourth Gospel the testimony is the same as in the Synoptics, with John's testimony to his recognition of the Messiah by the fact that the Spirit of God came down and abode on Him. In John iii. 34 Jesus speaks of Him whom God sent speaking the words of God, because God gives not the Spirit by measure unto Him, and in vi. 63, Jesus claims that the words which He speaks are spirit and life.

We find therefore that the reason for our Lord's words being able to stand alongside the Holy Spirit-ministered Scriptures, when the human traditions of the Pharisees were rejected, is that the Spirit was active in Him. The Spirit will not contradict Himself, nor cause that which was previously recorded to be broken.

Is there any parallel in the Epistles to Christ fulfilling the Law in the Gospels? The answer is that there is. Paul speaks of Christ being 'the end (telos) of the law for righteousness to every one that believeth' (Rom. x. 4). The conclusion to which the evidence points is that the true paradosis on the Old Testament Scriptures is Christ Himself, the Spiritanointed Messiah.

This conclusion is confirmed when we look at the content of the tradition according to the Scriptures; Colossians ii. 6 : "As ye have therefore received (parelabete) Christ Jesus the Lord, so walk ye in him.' That which had been delivered to them and which they had received was summed up in the Person of our Lord Jesus Christ, the Christian paradosis. 1 Corinthians xv. 1-11, 'The gospel which I preached unto you, which also ye have received (parelabete), and wherein ye stand (hestekate) ... if you 
hold fast (katechete) . . . for I delivered to you at the first that which also I received ...' is followed by a catalogue of the facts of Christ and His death and resurrection. 1 Corinthians xi. 23, if taken to refer to tradition and not direct revelation from God, may be taken as evidence and tells of the institution of the Lord's Supper. Romans vi. 17, 'Ye were the servants of sin, ye became obedient from the heart to that form of teaching whereunto ye were delivered (paredothète).' The very heart of that form of teaching was Christ Himself. So in Colossians ii. 8, walking kata tēn paradosin tön anthrōpon is regarded as the opposite of walking kata

The content of the tradition then is the Lord Himself, and this is the true divine tradition because of the ministry of the Spirit in the Lord, a error. They were adding and contradicting, but Christ was fulfilling and completing. Yet what of the ministry of this Christian tradition? Its content may be irreproachable, but can we be sure that what we have is the true account of Christ? Does the Spirit have any part to play in authenticating the tradition and ensuring its purity through the ages?

The first thing that we notice in this connection is that the apostles were quite sure that their teaching was authoritative and ought to be were quite sure that their teaching was
obeyed. 'I praise you that ye remember me in all things, and hold fast
the traditions, even as l delivered them to you' (1 Cor. xi. 2, Rv). "Therefore, brethren, stand fast (stékete), and hold fast (krateite) the traditions which ye have been taught, whether by word, or our epistle' (2 Thes. ii. 15). -Withdraw yourselves from every brother that walketh disorderly, and not after the tradition which he received of $u s^{\prime}$ ( 2 Thes. iii. 6). The reference to the tradition by epistle is especially instructive, in the light of $1 \mathrm{Tim}$. v. 18 and 2 Peter iii. 16, where apostolic writings are placed alongside Scripture and described as such. Again, Peter describes the Christian faith in 2 Peter $\mathrm{i}$ as not being based on cunningly devised fables, but based on the eye-witness report of the apostles and the more sure word of prophecy. The apostolic witness and the word of prophecy are placed on the same authoritative level.

Before the apostolic claim to authority can be investigated further, reference must be made to the important article of Oscar Cullmann in the book The Early Church (S.C.M., London, 1956). His main thesis is that when Paul refers in 1 Cor. xi. 23 to the institution of the Lord's Supper, he maintains that he received it apo tou Kuriou, and that this means that he received it from the Lord who is risen and ascended and who was then present and active in the transmission of the tradition, even though Paul heard the account from some human intermediary. Opinions before this time have varied between a personal divine revelation to the apostle and a chain of tradition reaching back ultimately to the Lord.

There is not space in this paper to trace the whole line of argument, but the salient features are these. The use of apo is used of the immediate source in Colossians i. 7 : 'Ye received from Epaphras (apo Epaphra)'. Cullmann might also have quoted John xiv. 10, where our Lord uses apo in a very similar sense, saying that the words which He speaks are not spoken $a p^{\prime}$ emautou as the immediate source. Cullmann agrees with $\mathrm{E}$. B. Allo that the use of $k a i$ in the phrase "that which also I delivered unto you' means 'I handed on in the same way as I received it myself, namely through a human intermediary'. The immediate source of the tradition in our Lord, and the use of human intermediaries lead Cullmann to postulate that the Lord is at work in the tradition and ensuring its correct transmission.

Certainly it is difficult to be certain exactly what Paul did mean, whether divine revelation or tradition, and commentators are divided, although most modern ones incline to the latter view. But if Cullmann is right, then this passage is a key one for the understanding of our subject, for here Paul is claiming that the risen and ascended Lord is at work in the transmission of the tradition even though Paul heard it through human lips. In the light of this it is interesting to read that in some places Paul appeals to the tradition and in others to the Lord, or the Word of the Lord. Thus in 1 Corinthians vii. 10, ' . . I I command, yet not I, but the Lord', and Ephesians iv. 21, where he refers to the Ephesians as having heard Christ, although they had not heard Him in the flesh. 
The obvious conclusion which Cullmann draws is that the Lord speaking and the tradition are one and the same. Now this is a stupendous claim, and it is here that we return to the consideration of the work of the Holy Spirit and tradition and turn to the Gospel according to St. John and the pneumatic passages of chapters xiv-xvi.

In these chapters the work of the Spirit is described as being to teach all things, to bring all things to remembrance, to lead to all truth, to show things to come, and to bear witness (xiv. 25, 26, xv. 26, xvi. 13). He is called the Spirit of truth. According to xvi. 12-14, He will not speak of Himself, but whatsoever He shall hear He shall speak. He is to take of the things of Christ and manifest them to the apostles. Therefore we might expect that the means by which the Lord is at work in the tradition is by His Spirit. We are familiar with the phraseology of our Lord in speaking of coming Himself and of sending His Spirit, as though these were synonymous terms, and correspondingly, just as Paul sometimes claims the authority of the tradition and sometimes the authority of the Lord, so we find references to the Spirit speaking in the New Testament. Thus in the Apocalypse, time and time again in the messages to the.churches there comes the refrain 'let him hear what the Spirit saith unto the churches'. Again, in 1 Timothy iv. 1, 'the Spirit speaketh expressly' that some shall depart from the faith in the last days. This compares closely with 1 Thessalonians iv. 15, where 'we say unto you by the word of the Lord' is followed by reference to the second advent. The Spirit speaking and the Word of the Lord are coterminous. So in 2 Corinthians iii we have the contrast between the Old and New Covenant, the difference being that the New is a ministry of the spirit, and in the same passage there is that difficult equation that 'the Lord is that Spirit'. Cullmann points out this close language and then refers to the prophecy of Jeremiah $x \times x i$ in which the New Covenant is concerned with a law written on the hearts. Ezekiel xxxvi. 26 reveals further that the means of the Law being written on men's hearts is the Spirit within them. The Lord as the new Law and the Spirit are again joined together.

When therefore the apostles are claiming authority for the traditions which they hand on, they are doing so because the Spirit is at work in them. This means that the Lord is working through them and their traditions are therefore not the traditions of men. Yet the gift of the Spirit was not the sole prerogative of the apostles. The Church of succeeding generations also has the Spirit. Is it therefore true, as the Roman Church claims and as Chrysostom said, that 'Today also it is the same One who produces and delivers everything, even as at this time'?

The answer of the Scripture is in the negative, for although the gift of the Spirit is not limited to the apostles, there is a limitation in John Xv. 27 which is most important. The Spirit is to bear witness of Christ, ' and ye also shall bear witness, because ye have been with me from the beginning.' The special witness of the Spirit is in this way limited to eyewitnesses. In this respect the apostles possessed a unique gift that was not perpetuated. Cullmann emphasizes this point by reference to John xvii, where the apostles are prayed for separately from those who should believe on Christ through their word. Peter was conscious of his own right to speak in Acts v. 32 : "And we (emph. the apostles) are his witnesses of these things; and so is also the Holy Ghost.' The qualification of the apostles is that they must have been eyewitnesses of Christ, and often the qualification of the apostle is dealt with in a passage which emphasizes the tradition. Paul is speaking of the Spirit's revealing work in 1 Corinthians ii when he says that things which God had kept from previous generations $\mathrm{He}$ had revealed ' unto us by his Spirit', and 'we have received, not the spirit of the world, but the spirit which is of God ; that we might know the things that are freely given to us of God. Which things also we speak, not in the words which man's wisdom teacheth, but which the Holy Ghost teacheth.' The Spirit is concerned with the handing on of the tradition as well as its revelation. Luke is careful in the prologue of his Gospel to point out that he was ' setting forth in order a declaration of those things which are most surely believed among us, even as they delivered (paredosan) them unto us, which from the beginning were eyewitnesses, and ministers of the word'. This limitation to the apostolic eyewitness is borne out by 
Ephesians iii. 4, 5, where Paul speaks of the 'mystery of Christ which in other ages was not made known ; . as it is now revealed unto his holy apostles and prophets by the Spirit'. Two classes were entrusted with the revelation of the truth, one of which was the apostles and the other the prophets. We have no record of the testimony of the charismatic prophets, but we have the testimony of the apostles, and they received the truth 'by the Spirit'.

Conscious of this ministry of the Spirit through the apostolic eyewitness, Peter finds no difficulty in placing the same eyewitness testimony on a level with the prophecy of old time, when holy men of God were moved by the Holy Ghost. The Holy Spirit was at work in both Old Testament Scripture and in the true New Testament tradition.

If this conception of the work of the Spirit in the content and transmission of the tradition is correct, and the work He exercises in this respect is limited to the apostolic witness, then any tradition which occurs beyond that limitation can only be the tradition of men. Also, we speak rightly when we say that the Lord spoke to us, when we really mean that the Word of God has come home to us in a certain way. Reliance upon the Scriptures as our final authority is not looking back to a static book, for just as the Spirit was active in speaking through the apostles then, so $\mathrm{He}$ is active in speaking through the apostolic witness now. The Word of God is indeed the Spirit's sword.

Cambridge.

D. J. V. LANE.

\section{THE NATURE AND PURPOSE OF THE CHARISMATA}

There have been many divergent evaluations of the nature and purpose of the charismata, or spiritual gifts, which occupy such a prominent place in the life of the early Church. From the various incomplete lists of charismata which are given in the New Testament (Rom. xii. 6-8; 1 Cor. xii. 4-11, 28-30 ; cf. Eph. iv. 7-12) it is evident that their number, variety and diffusion were considerable. Yet each gift had its source in the effectual working of the Holy Spirit and was intended to edify the Body of Christ.

Liberal theologians have been prone to deny the miraculous character of the charismata, and represented them as the natural manifestations of primitive enthusiasm ${ }^{1}$. By the end of the second century this spirit of enthusiasm gave way to 'a more rigid and disciplined Church Order, in which the official tended more and more to supersede the charismatic ministries '.2 The spiritual gifts began to disappear, but, being the product of an abnormal mental state, were liable to emerge under similar conditions in later religious revivals ${ }^{2}$. Certain gifts, such as prophecy and glossolalia, were largely regarded as particular manifestations of familiar phenomena of the Hellenistic age."

By way of contrast, the Roman Catholic theologians have acknowledged the divine origin of the charismata, and have gone on to affirm the permanence of certain gifts in the Church, notably the miracles of healing and other miraculous powers. Support for this general point of view has laid claim to the continuing reality of the powers of miraculous healing and the gift of tongues. In recent years there has been a widespread revival of interest in healing in every branch of the Church and attempts are being made to restore the gift of healing, which was lost (so it is said) as a result of a decline in faith and spirituality, and a growth of asceticism, about the time of the conversion of Constantine in AD $325 .^{\mathrm{s}}$ Similar reasons are often given for the decline of prophecy at a somewhat earlier date, though there have not been wanting those who have said that neither prophecy nor healing have entirely ceased in the history of the Church.

One of the most popular views of the charismata is that advanced by a school of Anglican divines at the beginning of the eighteenth century. This school maintained that the charismata were given for the purpose of founding the Church, and were gradually withdrawn when the Church became strong enough to continue without their assistance. The date for 